\title{
Northernmost record of the pantropical portunid crab Cronius ruber in the eastern Atlantic (Canary Islands): natural range extension or human-mediated introduction?
}

\author{
José A. González ${ }^{1}$, Raül Triay-Portella ${ }^{1}$, Aitor Escribano ${ }^{2}$, José A. Cuesta ${ }^{3}$ \\ ${ }^{1}$ Ecología Marina Aplicada y Pesquerías, i-UNAT, Universidad de Las Palmas de Gran Canaria, Campus Universitario de \\ Tafira, 35017 Las Palmas de Gran Canaria, Spain. \\ (JAG) (Corresponding author) E-mail: pepe.solea@ulpgc.es. ORCID-iD: http://orcid.org/0000-0001-8584-6731 \\ (RT-P) E-mail: emap.raul@ gmail.com. ORCID-iD: http://orcid.org/0000-0002-7591-6254 \\ ${ }^{2}$ Université de Liège, 7 Place du 20 Août, 4000 Liège, Belgium. \\ (AE) E-mail: aitoresc@ gmail.com. ORCID-iD: http://orcid.org/0000-0002-1405-5227 \\ ${ }^{3}$ Instituto de Ciencias Marinas de Andalucía, CSIC, Avda. República Saharaui, 2, 11519 Puerto Real, Cádiz, Spain. \\ (JAC) E-mail: jose.cuesta@ icman.csic.es. ORCID-iD: http://orcid.org/0000-0001-9482-2336
}

\begin{abstract}
Summary: The pantropical crab Cronius ruber (Lamarck, 1818) (Brachyura: Portunidae) is recorded for the first time from the Canary Islands. Previously known from off Cape Verde Islands and Senegal, this is the northernmost record of the species in the eastern Atlantic Ocean. Crabs have been caught by means of a collecting small trap for sampling in shallow waters, and then identified by both morphological characters and DNA barcoding (16S). Cytochrome c oxidase I partial sequence has been obtained for this species for the first time. This relatively large and very aggressive crab species seems to be rapidly occupying both hard substrates (sublittoral caves) and soft substrates (sand with seagrass meadow) adjacent to shallow rocky bottoms, at depths between 2 and $10 \mathrm{~m}$, in the warm southern waters of Gran Canaria Island. The reasons for this species' occurrence are discussed herein. Among them, natural range extension may be a consequence of tropicalization in the eastern Atlantic. Also, a human-mediated introduction could be based on the heavy traffic of ships (ballast waters or oil platforms) arriving at the Canary Islands from African countries and from Brazil in the last decade.
\end{abstract}

Keywords: zoogeography; natural expansion; anthropogenic introduction; Brachyura; crab; Cronius ruber; Canary Islands; eastern Atlantic; DNA barcoding.

Cita más septentrional del cangrejo portúnido pantropical Cronius ruber en el Atlántico oriental (Islas Canarias): ¿expansión natural o por causas antropogénicas?

Resumen: El cangrejo pantropical Cronius ruber (Lamarck, 1818) (Brachyura: Portunidae) es citado por primera vez en las Islas Canarias. Previamente conocido de las Islas Cabo Verde y Senegal, el presente constituye el registro más septentrional de esta especie en el Atlántico oriental. Los cangrejos fueron recolectados mediante un arte de trampa (pequeña nasa usada para muestreo en aguas someras) y posteriormente identificados a partir de sus caracteres morfológicos y mediante código de barras genético (DNA barcoding (16S)). La secuencia parcial del gen de la citocromo c oxidasa I de esta especie fue obtenida por primera vez. Este cangrejo de relativo gran tamaño y gran agresividad parece estar ocupando rápidamente tanto sustratos duros (cuevas sublitorales) como blandos (arena con pradera de fanerógamas) adyacentes a fondos rocosos someros, a profundidades comprendidas entre 2 y $10 \mathrm{~m}$, en aguas cálidas de la costa meridional de la isla de Gran Canaria. Se discuten en este trabajo diferentes causas que explican la aparición de esta especie en Canarias. Entre otras, la expansión natural como consecuencia del proceso de tropicalización en el Atlántico oriental. Además, una introducción por causas antropogénicas puede estar basada en la intensificación del tráfico pesado de naves (aguas de lastre o plataformas petrolíferas), que llegan hasta Canarias desde países africanos y Brasil en la última década.

Palabras clave: zoogeografía; expansión natural; introducción antropogénica; Brachyura; cangrejo; Cronius ruber; Islas Canarias; Atlántico oriental; código de barras genético.

Citation/Como citar este artículo: González J.A., Triay-Portella R., Escribano A., Cuesta J.A. 2017. Northernmost record of the pantropical portunid crab Cronius ruber in the eastern Atlantic (Canary Islands): natural range extension or humanmediated introduction? Sci. Mar. 81(1): 81-89. doi: http://dx.doi.org/10.3989/scimar.04551.17B

Editor: Ch. Zeng.

Received: September 15, 2016. Accepted: December 19, 2016. Published: January 20, 2017.

Copyright: (9) 2017 CSIC. This is an open-access article distributed under the terms of the Creative Commons Attribution (CC-by) Spain 3.0 License. 


\section{INTRODUCTION}

After decades of ocean warming, an increasing number of works have postulated a tropicalization of species assemblages in temperate biogeographic transition zones such as southwestern Australia (Wernberg et al. 2016), some parts of the Mediterranean (Horta Costa et al. 2014), the NW of the Iberian Peninsula (Cuesta et al. 2016) and the Macaronesian archipelagos in the northeastern Atlantic (Brito et al. 2005, Wirtz et al. 2008, Afonso et al. 2013). This process has been associated with global warming in many cases (Perry et al. 2005, Occhipinti-Ambrogi 2007, Wernberg et al. 2016). In response to warmer conditions, marine species tend to shift their distributions to higher latitudes, and organisms are predicted to keep shifting under climate change scenarios (e.g. Perry et al. 2005). Some recent reviews have accounted for this topic in temperate marine ecosystems, emphasizing that climate-driven changes in biotic interactions can profoundly alter ecological communities and reconfigure ecosystems, and are expected to have important social and economic implications (Vergés et al. 2014, Wernberg et al. 2016).

Within the Macaronesian ecoregion (Azores-Madeira-Canaries) of the Lusitanian biogeographic province, the Canary Islands region occupies its southern frontier, limiting with the warmer West African Transition province (Spalding et al. 2007). Moreover, the Canary Islands are located in front of the northwestern coast of Africa (104 km from Morocco). The Canaries are under the influence of the subtropical gyre of the eastern-central Atlantic, which facilitates the transport of planktonic larvae and rafting organisms to the archipelago. Average seawater temperature around these islands is $18.5^{\circ} \mathrm{C}$ in February, rising abruptly to $24^{\circ} \mathrm{C}$ in August-September (Barton et al. 1998). A distribution of larval communities has been described in filaments of the upwelling system from the African coast reaching the archipelago (e.g. Landeira et al. 2009). Also, the Canaries are geographically located on a very important maritime route, and both ships (Brito et al. 2011, González et al. 2012) and oil platforms (Triay-Portella et al. 2015, Pajuelo et al. 2016) have been recognized as major vectors for the introduction of non-indigenous species.

Human-caused introduction and spread of nonnative species are considered one of the main threats to marine biodiversity, and the degree of interest in introduced species has increased worldwide in recent years (Streftaris et al. 2005, Molnar et al. 2008, Galil et al. 2011). Biological invasions are a growing environmental problem because non-indigenous organisms may affect the structure and functioning of native communities (Molnar et al. 2008, Galil et al. 2011, Sant'Anna et al. 2012).

During the last 30 years, the occurrence and even establishment of non-native marine species around the Canary Islands have been reported, and the arrival of subtropical/tropical fishes (Brito et al. 2005, Triay-Portella et al. 2015, Pajuelo et al. 2016) and crustaceans (González et al. 2012, Moro et al. 2014, González 2016) has increased.
To date, according to González (2016), the portunoid family Portunidae Rafinesque, 1815 is represented in Canary Islands waters by four sublittoral species: Laleonectes vocans (A. Milne-Edwards, 1878), Portunus (Portunus) hastatus (Linnaeus, 1767), Portunus (Portunus) inaequalis (Miers, 1881) and Thalamita poissonii (Audouin, 1826).

This paper records for the first time the presence and spread of the pantropical crab Cronius ruber (Lamarck, 1818) (Portunidae) in the Canary Islands. Previously known from off Cape Verde Islands and Dakar, Senegal (Monod 1956, Manning and Holthuis 1981, Fransen 2015), this is the northernmost record of the species in the eastern Atlantic. Crabs have been identified by both morphological characters and DNA barcoding (16S). The reasons for occurrence of this species at this latitude are discussed herein.

\section{MATERIALS AND METHODS}

An experienced fisherman working in the area provided us with photographic evidence (they were eating a crab new to the Canaries!) and then with four live specimens of a brachyuran species unknown to him collected at Castillo del Romeral, on the southeastern coast of the island of Gran Canaria (Canary Islands, northeastern Atlantic) in early June 2016. This first set of crab individuals were captured by hand from hard bottoms, in sublittoral caves at depths between 8 and $10 \mathrm{~m}$ (approximately at $27^{\circ} 47^{\prime} 31^{\prime \prime} \mathrm{N} 15^{\circ} 28^{\prime} 22^{\prime \prime} \mathrm{W}$ ) (Fig. 1).

From late June to early July 2016, in the framework of an overall ecological study on brachyuran crabs from sand with Cymodocea nodosa seagrass meadows at Bahía de Santa Águeda, on the southwestern coast of Gran Canaria, some individuals of the same brachyuran species were observed and video-recorded, and then a second set (22 specimens) were captured on these soft substrates, at depths between 2 and $10 \mathrm{~m}$ (approximately at $\left.27^{\circ} 45^{\prime} 13^{\prime \prime} \mathrm{N} 15^{\circ} 40^{\prime} 46^{\prime \prime} \mathrm{W}\right)$. These crabs were caught by means of a small, ad hoc collecting trap for sampling in shallow waters. Each trap measured 46×20 $\mathrm{cm}$ base length and $20 \mathrm{~cm}$ in height, was covered with $1 \times 2 \mathrm{~mm}$ mesh, and had one $16 \times 6 \mathrm{~cm}$ truncoconical opening (Triay-Portella et al. in prep.). Each trap was baited with pieces of frozen Spanish mackerel.

Each crab specimen was taxonomically identified in the laboratory by checking their morphological characters with suitable bibliography on Atlantic subtropical/tropical portunids (i.e. Monod 1956, Manning and Holthuis 1981, Spiridonov et al. 2014). Systematic classification follows $\mathrm{Ng}$ et al. (2008), but also takes into account the latest changes in Portunoidea (Schubart and Reuschel 2009, Spiridonov et al. 2014).

For the purposes of the present paper, standard carcinological measurements were taken using Vernier callipers $( \pm 0.1 \mathrm{~mm})$, following Attrill et al. (1991) and the update by Biscoito et al. (2015): carapace width $(\mathrm{CW})$, defined as the maximum transversal diameter at the midline of the carapace, excluding the ninth dorsolateral spines; and carapace length (CL), defined as the longitudinal distance from the rostral teeth to the posterior carapace margin. $\mathrm{CW}$ and $\mathrm{CL}$ were taken on 


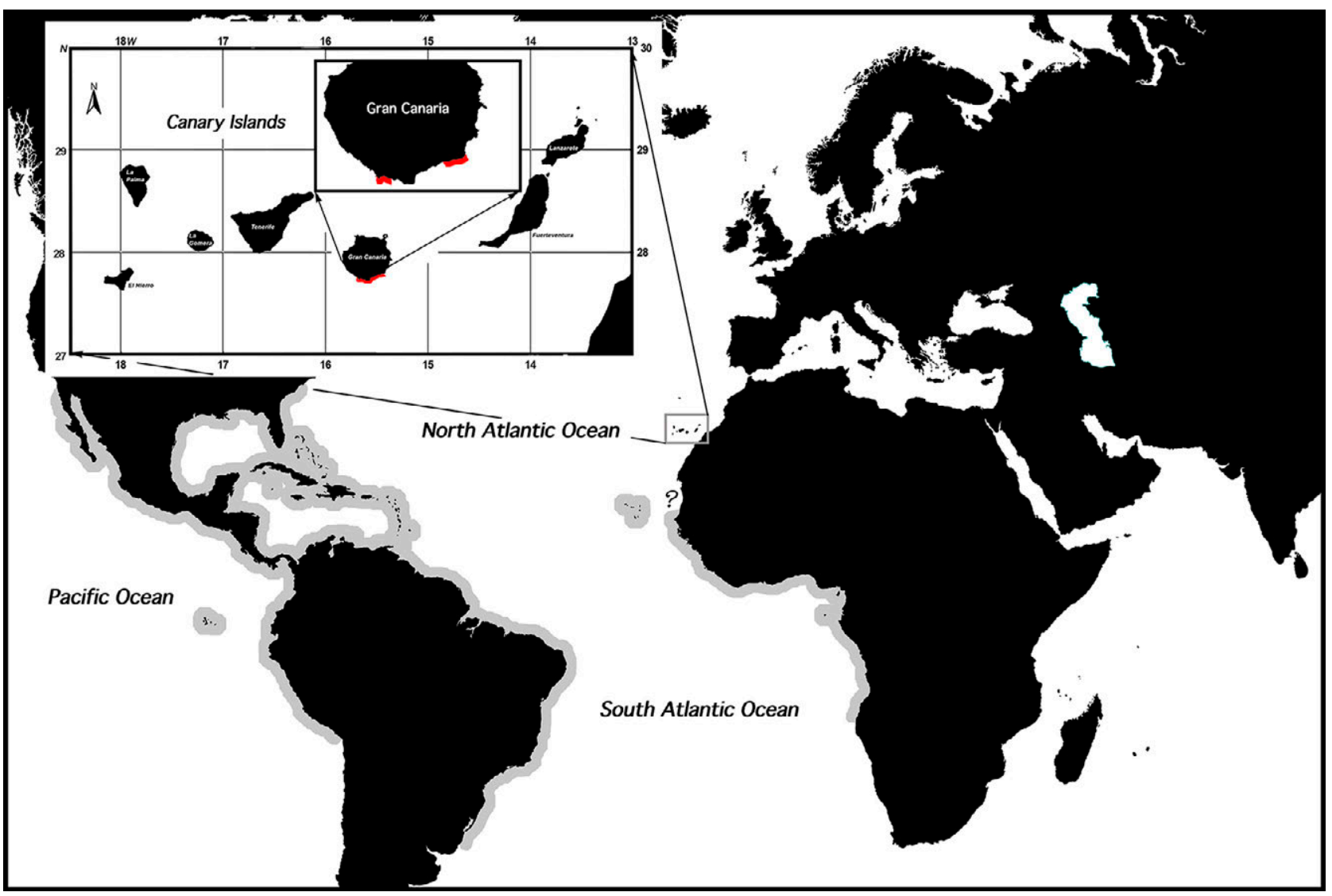

Fig. 1. - Geographic distribution of Cronius ruber (Lamarck, 1818), including present collection locations on the Canary Islands coasts, eastern Atlantic.

Table 1. - Descriptive statistics for carapace width (CW, mm) and carapace length (CL, $\mathrm{mm}$ ) by sexual groups and habitats of Cronius ruber (Lamarck, 1818) from the Canary Islands.

\begin{tabular}{|c|c|c|c|c|c|}
\hline & \multirow{2}{*}{$\mathrm{n}$} & \multicolumn{2}{|c|}{ Carapace width (mm) } & \multicolumn{2}{|c|}{ Carapace length (mm) } \\
\hline & & minimum & maximum & minimum & maximum \\
\hline \multicolumn{6}{|c|}{ Hard bottom (sublittoral caves) } \\
\hline Males & 3 & 64.43 & 81.20 & 40.53 & 54.70 \\
\hline Females & 1 & 53.44 & 53.44 & 35.12 & 35.12 \\
\hline \multicolumn{6}{|c|}{ Soft bottom (sand-seagrass meadow) } \\
\hline Males & 18 & 58.19 & 75.96 & 33.37 & 49.54 \\
\hline Females & 2 & 50.98 & 51.90 & 34.31 & 34.45 \\
\hline Ovigerous females & 1 & 53.85 & 53.85 & 36.35 & 36.35 \\
\hline Both substrata combined & 25 & 50.98 & 81.20 & 33.37 & 54.70 \\
\hline
\end{tabular}

the upper side of the crab, in the left-right and anteriorposterior direction, respectively. Sex (based on abdomen morphology and presence/absence of gonopods) and ovigerous condition (based on the presence of external or remaining eggs on the pleopods) were also recorded. Number, sex, ovigerous condition and size of all vouchers by type of substrata are presented in Table 1.

The only ovigerous female collected was used for the morphological study of eggs and to preliminary estimate fecundity. Following Triay-Portella et al. (2014), pleopods with attached eggs were removed, and egg mass was then placed on a $100-\mathrm{mm}$ mesh, washed and isolated from pleopods. After removal of the excess wash water, 40 eggs were measured in sea water.

Voucher specimens were labelled, curated, databased and deposited, available for verification (Turney et al. 2015), in the ICCM study collection at the University of Las Palmas de Gran Canaria.
Traffic information of oil platforms in the Port and Bay of Las Palmas between 2010 and 2015 was obtained from local newspapers, port logs and annual reports of activities of the port authority. Information gathered allowed Pajuelo et al. (2016) to build the main routes of oil rigs arriving in Gran Canaria. These routes and the chronology of voyages were used to check coincidences with the occurrence of the newly recorded crab.

DNA barcode sequences were obtained for a male specimen (76.13 mm CW, $49.05 \mathrm{~mm} \mathrm{CL}$ ) of Cronius ruber collected off the Canary Islands and deposited in the ICCM study collection under the accession code ICCM422. Equivalent sequences were also obtained for a female specimen of Cronius ruber from Guinea deposited in the IEO Crustacean Decapod Collection at Cadiz Oceanographic Centre under the accession code IEO-CD-CCLME11/719.

The molecular confirmation of the identification of the crabs was based on a partial sequence of the mi- 


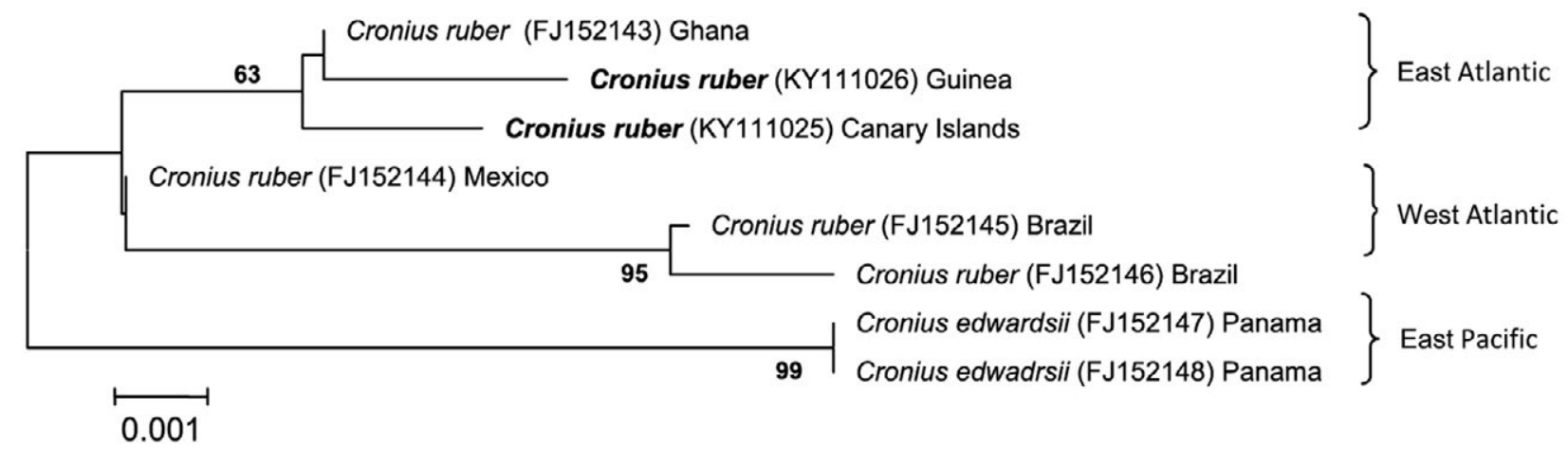

Fig 2. - Topology of neighbour-joining tree based on 513 bp of the $16 \mathrm{~S}$ gene partial sequences, showing inferred phylogenetic relationships of representatives of the genus Cronius Stimpson, 1860. Numbers close to nodes indicate bootstrap support (only values above 50\% shown). GenBank accession numbers are shown after name of species.

tochondrial gene $16 \mathrm{~S}$ mtDNA, but a partial sequence of the Cytochrome c oxidase subunit I (COI) was also obtained. Total genomic DNA was extracted from muscle tissue from one pereiopod, following a modified Chelex 10\% protocol by Estoup et al. (1996).

Target mitochondrial DNA from the 16S rRNA and COI genes was amplified with polymerase chain reaction (PCR) using the following cycling conditions: 2 $\min$ at $95^{\circ} \mathrm{C}, 40$ cycles of $20 \mathrm{~s}$ at $95^{\circ} \mathrm{C}, 20 \mathrm{~s}$ at $45^{\circ} \mathrm{C}$ (COI) or $48^{\circ} \mathrm{C}(16 \mathrm{~S}), 45 \mathrm{~s}(16 \mathrm{~S})$ or $47 \mathrm{~s}(\mathrm{COI})$ at $72^{\circ} \mathrm{C}$, and 5 min at $72^{\circ} \mathrm{C}$. Primers $1472\left(5^{\prime}-\mathrm{AGA}\right.$ TAG AAA CCA ACC TGG-3') (Crandall and Fitzpatrick 1996) and 16L2 (5'-TGC CTG TTT ATC AAA AAC AT-3') (Schubart et al. 2002) were used to amplify 516 bp of 16S, while primers COH6 (5'- TAD ACT TCD GGR TGD CCA AAR AAY CA -3') and COL6b (5'- ACA AAT CAT AAA GAT ATY GG -3') (Schubart and Huber 2006) were used to amplify 634 bp of COI. The PCR products were sent to Stab-Vida Laboratories to be purified and then bidirectionally sequenced.

Sequences were edited using the Chromas software version 2.0. With the obtained final DNA sequences, a BLAST search was executed on the NCBI webpage to get the sequence that best matched. All DNA sequences obtained were deposited in GenBank under accession numbers KY111025 to KY111028.

An evolutionary distances analysis was carried out in MEGA6 (Tamura et al. 2013). Alignment of $16 \mathrm{~S}$ sequences was built using sequences obtained from the specimens studied as well as from the other congeneric species downloaded from GenBank (http://www.ncbi.nlm.nih.gov, FJ152143 to FJ152146). The phylogeny reconstruction analyses were inferred from neighbour-joining using the p-distance method. The nodal confidence of the obtained topologies was assessed via 2000 bootstrap replicates (Fig. 2).

\section{RESULTS}

One brachyuran decapod species, Cronius ruber, has been newly recorded for the Canary Islands herein, and this represents the northernmost record $\left(27^{\circ} 47^{\prime} 31^{\prime \prime} \mathrm{N}\right)$ of the species in the eastern Atlantic Ocean (Fig. 1). This is also the first record for the genus Cronius Stimpson, 1860 from the Canary Islands, and $C$. ruber is the fifth portunid (Portunidae) recorded from the Canaries (cf. González 2016). The present newly accounted species increases the Canarian brachyuran carcinofauna to 133 marine species (cf. González 2016).

\section{Material examined and morphologic identification}

Material examined was collected at two localities: 1) Castillo del Romeral, 6 June 2016, hard bottom (sublittoral caves), 8-10 m, three males and one non-ovigerous female (ICCM422); and 2) Bahía de Santa Águeda, 25 June to 14 July 2106, soft bottom (sand-Cymodocea nodosa seagrass meadows) adjacent to shallow rocky bottoms, 2-10 m, 2 quelipeds, 18 adult males, 2 adult females (ICCM423) and 1 ovigerous female (ICCM424) (Fig. 1). Size ranges for different sexual/habitat groups and combined are given in Table 1.

All specimens of the blackpoint sculling crab collected agree well with the descriptions given for the species, in particular with the distinguishing characters and iconography provided by Monod (1956) and Manning and Holthuis (1981). Colouration in live or freshly-caught specimens examined matches well with the detailed colour account given by Capart (1951) and Rossignol (1957) from African material. However, the present material comprises individuals exhibiting two colour patterns (carapace, dorsal part), a reddish pattern (=ruber) and a greenish pattern, with apparently no morphological differences between them (Fig. 3). Blackpoint (from common name) very probably refers to the dark apex of the dorso-lateral and rostral teeth (Fig. 3). When compared with those of other Atlantic portunid species, it is noteworthy that carapace dorsolateral teeth are alternating in size in Cronius species: first (inner orbital tooth), third, fifth, seventh and ninth (the strongest) larger than second, fourth, sixth and eighth, noticeably directed dorso-anteriorly (Fig. 3).

According to Manning and Holthuis (1981), there is a possibility that the West African population of $C$. ruber should be recognized as different from the American population on the basis that adults of the former population appear to differ from the latter one in the colour pattern and ornamentation of the chelae. It is noteworthy to mention here that the genus Cronius currently has another accepted species, the crevice sculling crab, Cronius tumidulus (Stimpson, 1871), which 


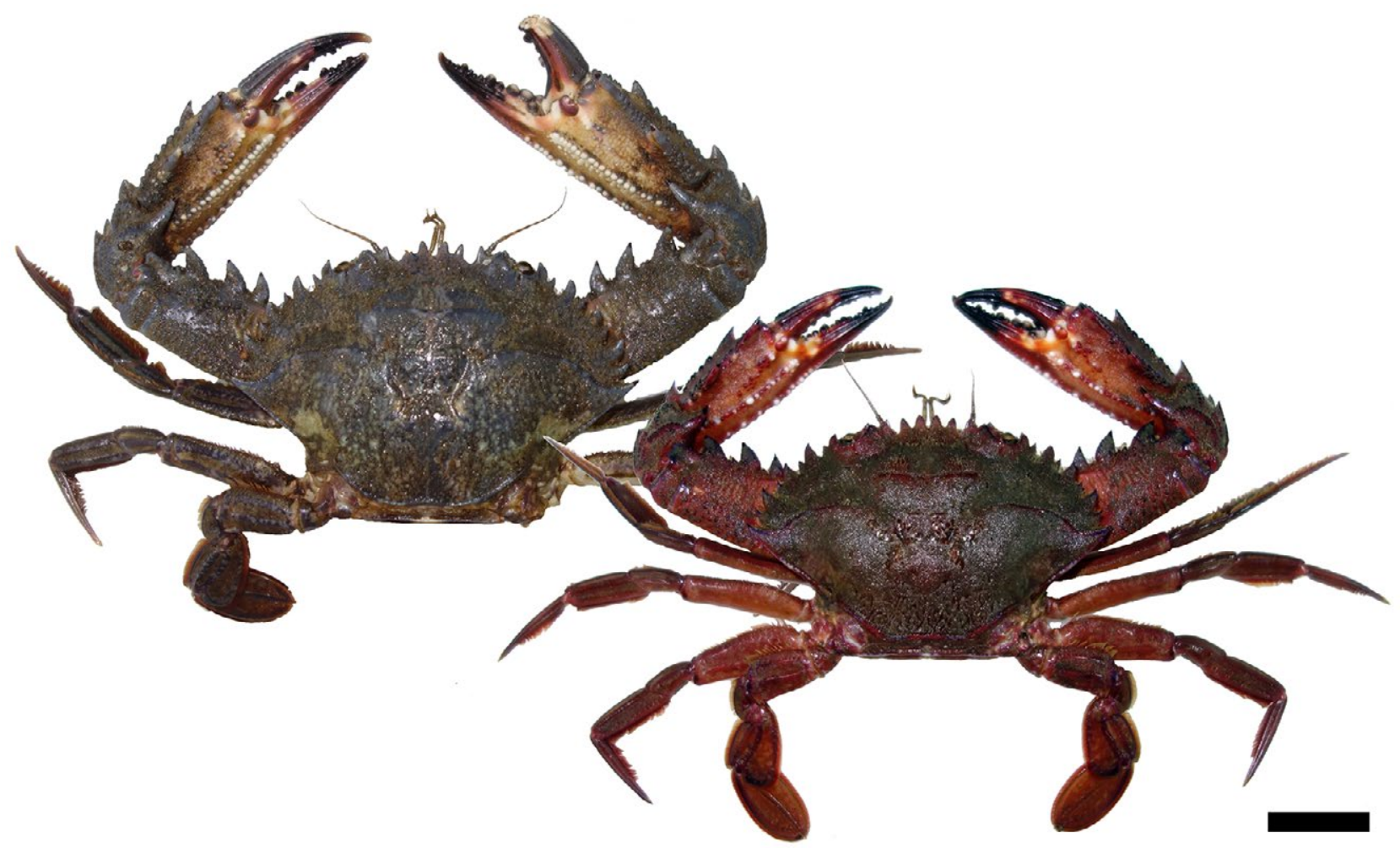

Fig. 3. - Cronius ruber (Lamarck, 1818) from the Canary Islands. Males, dorsal view, greenish (ICCM422, 81.20×54.70 mm) and reddish (ICCM423, 68.53×43.86 mm) colour patterns.

is only known from the Gulf of Mexico (Mantelatto et al. 2009, Davie 2015).

Monod (1956) examined many specimens collected from several West African countries; however, the few measurements given only include one Senegalese juvenile measuring $11 \times 8 \mathrm{~mm}$, and one adult male from Sierra Leone measuring $82 \times 52 \mathrm{~mm}$. The material of Manning and Holthuis (1981) from the Ivory Coast, Ghana and Annobon had CWs of 10 to $72 \mathrm{~mm}$. The studied specimens (ranging 50.98-81.20 $\mathrm{mm} \mathrm{CW}$, and 33.37$54.70 \mathrm{~mm} \mathrm{CL}$ ) are well within the size ranges and CW/ CL proportions given for the species (Table 1).

\section{DNA barcoding}

In the absence of COI sequences available in GenBank, only a $16 \mathrm{~S}$ partial sequence confirmed the identification of the species.

The $16 \mathrm{~S}$ partial sequence obtained (516 bp) confirmed the identification of this species, since the specimen sequence fits $99 \%$ with the sequences of Cronius ruber from Ghana (SMF31986, GenBank accession number FJ152143), Mexico (ULLZ 6448, GenBank FJ152144) and Brazil (ULLZ4295, 4772, GenBank FJ152145, FJ152146). The sequence of the Canary specimen differs only in one mutation out of $513 \mathrm{bp}$ in comparison with the Ghana sequence, in two mutations in comparison with the Mexico sequence, and in five mutations in comparison with the Brazilian ones. All GenBank sequences were obtained in the context of the molecular phylogeny of the genus Cronius by Mantelatto et al. (2009). When compared with the 16S sequence obtained in this study for a specimen from Guinea, the fit was also $99 \%$ (differing only in one mutation).

In the obtained tree (Fig. 2), the sequence of Cronius ruber from the Canary Islands clusters in a supported clade with the sequences of the African specimens (Ghana and Guinea). Although specimens from the east Atlantic, west Atlantic and east Pacific form separate clades, there are no great distances among them, and these clades only show geographical separation at intraspecific level.

With regard to COI sequence, comparison is not possible with Cronius ruber specimens from America because no COI sequences are available in the GenBank database. However, when compared with the sequence of the Guinea specimen obtained in this study, only five mutations were found in $634 \mathrm{bp}$ (99\%). These DNA COI barcodes from the Canary Islands (KY111027) and Guinea (KY111028) specimens were deposited in GenBank and in the future, when new sequences of American specimens become available, comparison can be completed.

\section{Biology and ethology}

Cronius ruber was characterized as a eurythermic and euryhaline species occurring on all types of bottom (Le Loeuff and Intès 1968). A more recent compiled information of its western African habitats confirmed that it is a shallow-water species occurring on a variety of substrata, including mud, mud and sand, fine sands, coarse shelly sands, calcareous algae, shell 
gravels, rocks, rocks with algae, stones and boulders (cf. Manning and Holthuis 1981, Fransen 1991). Off West Africa, this species has been recorded from the intertidal (rock pools and low water mark) to the sublittoral zones to a depth of $69 \mathrm{~m}$, but the majority of depth records are from depths of $30 \mathrm{~m}$ or less (cf. Manning and Holthuis 1981, Fransen 1991).

The studied specimens were collected on both hard and soft bottoms at depths between 2 and $10 \mathrm{~m}$, which are well within the habitat and depth range given for the species. Hard bottoms were represented by some sublittoral caves in rocky substrata. Soft bottoms were arranged in a landscape formed by sand with Cymodocea nodosa seagrass meadows, adjacent to a rocky bottom dominated by rolling stones and pebbles. To our knowledge, neither habitats had been previously reported for this species.

Nocturnal activity was observed as a behaviour pattern; during daytime the blackpoint sculling crab hides in crevices and holes. When feeling threatened on soft bottoms, they burrow into sand. Feeding habits showed it to be an omnivorous species eating on algae with small invertebrates. Four pairs were observed while copulating, and one of them that was captured showed abrasions on the sexual pleopods and opened vulvae. Nearly all males collected have abrasions on the sexual pleopods. All these observations were made directly by the authors during the recent start of a biological/ecological study (see Materials and Methods, and Discussion).

Off West Africa, ovigerous females have been recorded in both winter (January and March) and summer (September), with juveniles being found more often than adults (cf. Manning and Holthuis 1981). Egg size in ovigerous females from Sierra Leone was reported to be between 0.28 and $0.30 \mathrm{~mm}$. The studied material includes one ovigerous female $(53.85 \times 36.35$ $\mathrm{mm}$ ) collected on 25 June carrying 474400 eggs (range 286.01-316.06 $\mu \mathrm{m}$; mean size $294.26 \mu \mathrm{m}$; sd \pm 8.43 $\mu \mathrm{m})$. These observations and evidences indicate that $C$. ruber has been already established in Canarian sublittoral ecosystems and has reproductive activity.

\section{Geographic distribution and biogeographic comments}

Cronius ruber is a pantropical species living in the Atlantic and east Pacific Oceans. In the east Pacific, it is found from Baja California (max Lat $32^{\circ} 31^{\prime} \mathrm{N}$ ), Mexico to Peru, including Clipperton Island and the Galápagos Islands. In the west Atlantic, it is found from South Carolina (max Lat $\left.33^{\circ} 49^{\prime} \mathrm{N}\right)$, USA to Brazil. In the east Atlantic, it is reported from Mauritania (questionable, Monod 1956: 190, "1 mâle ... l'échantillon a bien été envoyé de Port-Etienne, mais où a-t-il été recueilli?") and Senegal to Angola (12 $\left.36^{\prime} \mathrm{S}\right)$, including the Cape Verde archipelago and the islands of the Gulf of Guinea (Monod 1956, Manning and Holthuis 1981, Fransen 2015) (Fig. 1).

To our knowledge, to date the northernmost nonquestionable record of this species on the northwestern African coast has been published by Fransen (1991): off the southwestern coast of São Nicolau Island $\left(16^{\circ} 35^{\prime} \mathrm{N}\right)$, Cape Verde Islands. Accordingly, the present records from Canary Islands waters now fix the northernmost limit $\left(27^{\circ} 47^{\prime} 31^{\prime \prime} \mathrm{N}\right)$ of the species' distribution in the eastern Atlantic, i.e. around 825 nautical miles (more than 1500 kilometres) to the north of where it was previously known to occur (Fig. 1).

According to the main biogeographic patterns, the Canarian brachyuran biota (123 littoral and/or upperbathyal species occurring to $300 \mathrm{~m}$ depth) has recently been characterized as Atlanto-Mediterranean (39 species, $31.7 \%$ ) and Guinean (subtropical and tropical) (28 species, $22.8 \%$ ), with a small group of amphi-Atlantic species of warm affinity ( 5 species, $4.1 \%$ ) and another of pantropical or circumtropical species (4 species, $3.3 \%$ ) (cf. González 2016). The addition of C. ruber results in a fifty-fifty balanced composition of AtlantoMediterranean species $(31.4 \%)$ versus a mixture of warm affinity species $(30.6 \%)$.

\section{DISCUSSION}

All portunids previously occurring in Canary Islands waters appear to exhibit similar distributional (shallow-water species) and warm-affinity biogeographic patterns, as well as nocturnal and more or less sciaphilic habits. All of them inhabit from a few metres to a maximum depth of $60 \mathrm{~m}$ (P. hastatus), with the exception of $T$. poissonii, which reaches a maximum depth of 110-120 m (cf. González 2016).

L. vocans is an amphi-Atlantic species of warm affinity; its occurrence in the Canaries is based on 6 individuals ( 4 from Tenerife, and 2 from El Hierro) found in sublittoral sciaphilic caves (5-10 m) between 1994 and 2014 (cf. González 1995 as Portunus sp., Moro et al. 2014).

$P$. hastatus is a Guinean species first recorded from the Canaries by Brullé (1839, as Lupa hastata) and, since that time, regularly reported as a common species with a moderate well-established population nowadays (cf. González 1995, 2016); adults are typically found on sand and sandy-mud bottoms (González 1995), but juveniles have pelagic stages (Türkay 1987, reported on five juveniles near La Palma).

$P$. inaequalis is a Guinean species; it has recently been first recorded from the Canaries by González (2016), based on the finding of one individual from Tenerife (cave, $8 \mathrm{~m}$, in 2014) and another from Gran Canaria (at the base of a breakwater, $12 \mathrm{~m}$, in 2015).

T. poissonii is a pantropical species first recorded from the Canaries by Brullé (1839, as T. admete) and then regularly reported as a common species with apparently a moderate well-established population nowadays (cf. González 1995, 2016, Moro et al. 2014).

However, according to communications by fishermen working in the area, individuals of $C$. ruber suddenly appeared on the southern coast of Gran Canaria five or six years ago, resulting in a rapid colonization of sublittoral caves in rocky shores. It is not possible to establish a chronology on the colonization of these hard bottoms and also soft substrates characterized by sand with seagrass meadows (adjacent to rocky bot- 
toms). It probably colonized both habitats based on its biological and ecological traits (relatively large size, aggressiveness, swimming capacity) (e.g. Spiridonov et al. 2014), with the help of a set of local disorganized intertidal and sublittoral ecosystems with many vacant niches.

In the marine environment there are records of invasive species including crustaceans (Tavares and Mendonça 1996, Dauvin et al. 2009, González et al. 2012), and portunids of genera Charybdis De Haan, 1833 (Dineen et al. 2001, Tavares and Amouroux 2003, Sant'Anna et al. 2012), Callinectes Stimpson, 1860 (Molnar et al. 2008, Minchin et al. 2013, Manfrin et al. 2015) and Scylla De Haan, 1833 (Tavares and Mendonça 2011) are among the most widespread invasive groups.

The assessment of species-level ecological traits associated with the rafting behaviour has recently been proposed by Luiz et al. (2015) to better understand, and even predict, the species' capacity for long-distance oceanic dispersal in isolated areas of benthic habitats. They used a dual classification of seafarer or castaway species. Rafter species are "seafarers" because they possess traits that facilitate long oceanic journeys, whereas species marooned by chance in the flotsam are "castaways". Knowing their biological and ecological traits and their dispersal capacity, Canarian portunid species could be evaluated with the criteria of Luiz et al. (2015). Also, this information combined would be useful for discussing the establishment status of these species at the Canaries, and even for predicting future displacements to the north within the current scenario of tropicalization. In this regard, L. vocans and P. inaequalis, being markedly sciaphilic forms restricted to caves and similar habitats, seem to be castaway species. $P$. hastatus and T. poissonii, being capable of colonizing sandy and mixed (sandy gravels) bottoms, would be seafarer species. Finally, $C$. ruber, being capable of colonizing all types of substrata (from caves to sand vegetated bottoms), seems to possess the necessary ecological traits to be a typical invasive species. Therefore, an ambitious, in-depth biological and ecological study is now being implemented by the second author (RT-P). Its results will be published elsewhere.

Regarding the establishment status of the portunid species occurring in the Madeira archipelago (north of the Canary Islands, between 32 and $33^{\circ} \mathrm{N}$ ), L. vocans, $P$. hastatus and $P$. inequalis were first recorded by Türkay (1976) based on a few specimens deposited in the Funchal Natural History Museum; they have no local common name and seem to be rare or uncommon species in that archipelago. T. poissonii and C. ruber have not yet reached the Madeiran shores (cf. Araújo and Wirtz 2015) but, at least for $C$. ruber, its arrival there using the Selvages islets (at $30^{\circ} \mathrm{N}$, between the Canary and Madeira Islands) as stepping stones could probably be predicted. In this prediction one must take into account that $C$. ruber has been reported as high as $32-33^{\circ} \mathrm{N}$ in both the western Atlantic and eastern Pacific Oceans.

Based on the evidence gathered herein, two hypotheses can be proposed in order to explain the natural arrival to Gran Canaria Island, or the introduction route of the present genetically proven African individuals of C. ruber.

The first theory explaining the occurrence of $C$. ruber in Canary Islands waters is based on a natural range extension (i.e. a natural population expansion) as a result of the high oceanographic connectivity (trade winds, marine currents and larval flow, see Introduction section) between this archipelago and the neighbour northwestern African coasts. Dispersal capabilities depend on the mobility of the decapods in question. Adults of brachyuran portunids are benthic and have proven to have moderate-high capabilities for dispersal. As the larvae are pelagic, it is assumed that dispersal takes place during the larval phase. However, $C$. ruber larvae should have overcome the biogeographical boundary represented by the Banc d'Arguin (Fransen 1991, Spalding et al. 2007). This area coincides with the meeting point of the southwards, cooling Canary Current and the northwards, warming Guinea Current, and these currents may play a role in determining the faunal distributions in the region; the matter still remains unresolved (Fransen 2002). However, Mittelstaedt (1983) postulated that the only natural means of arrival to the Canaries of larvae of tropical African fauna is the possible occasional displacement of African waters by certain conditions of the wind from the south when the ascending coastal current (a reverse current) flows copiously past Cape Blanc and reaches Cape Bojador, an occurrence that appears to take place during winter.

The second theory explaining the occurrence of $C$. ruber in the Canary Islands is a human-caused introduction of one or more phases of its life cycle. The first plausible possibility would be ship ballast mediation and dispersal during the larval phase (Wonham et al. 2000, Brito et al. 2011, Galil et al. 2011). Many small benthic marine fishes, chordate species, small-sized invertebrates and plankton (introduced as eggs, larvae or juveniles) are first recorded from regions with major commercial ports, and the method of transport associated is via the large amounts of ballast water carried by international shipping (Wonham et al. 2000, Lockett and Gomon 2001) or ship's hull fouling (Cuesta et al. 2016).

A second possibility would be the transport of juvenile, subadult or/and adult crab specimens on oil platforms (Friedlander et al. 2014, Triay-Portella et al. 2015, Pajuelo et al. 2016). Oilrigs are large structures in the ocean where they act as artificial reefs and serve as an important habitat for a number of species (e.g. Atchison et al. 2008). These artificial habitats are colonized by diverse ecological communities, increasing the growth and survival of individuals and affording shelter for protection from predation and spawning substrate (e.g. Friedlander et al. 2014). There is a noteworthy coincidence between the establishment of oilrig maritime routes connecting the West African coast with Gran Canaria and the presumed occurrence of $C$. ruber on the coasts of this island. Recently, Pajuelo et al. (2016) reported the introduction of non-native marine fish species to the Canary Islands waters through 
oil platforms as vectors, mapping the main routes used by oilrigs arriving at Gran Canaria between 2010 and 2015. In the east Atlantic, a significant part of these voyages started from ports of Cape Verde Islands, the Ivory Coast, Cameroon, Nigeria, Congo-Brazzaville, Namibia and South Africa.

The present results from the DNA barcoding analysis clearly support an African origin for Cronius ruber from the Canary Islands. The low number of mutations in the $16 \mathrm{~S}$ sequences among specimens of the east Atlantic, west Atlantic and east Pacific indicate that they all belong to the same species (Cronius ruber) and only minor differences, based on geographical distances, were detected. The greatest distance was found between sequences of specimens from Brazil and Panama, with only eight mutations (98\%).

According to these data, pending new gene analysis, there is no support for distinguising Western African and eastern Pacific populations as Cronius milleri (A. Milne-Edwards, 1868) and C. edwardsii (Lockington, 1877), respectively.

Comparison of the $16 \mathrm{~S}$ and COI sequences obtained herein for $C$. ruber from the Canaries revealed a very high proximity to $C$. ruber specimens from Guinea $\left(10^{\circ} 27^{\prime} \mathrm{N} 14^{\circ} 56^{\prime} \mathrm{W}\right)$. Is this a coincidence or the result of crab introduction from the West African coast via ship ballast and/or oil platforms?

\section{ACKNOWLEDGEMENTS}

Thanks are due to Rayco García Habas, an experienced fisherman from Gran Canaria, who alerted us to the new crab and provided the first set of specimens. We also thank Eva García-Isarch, curator of crustaceans at the Spanish Institute of Oceanography, for allowing the DNA extraction of Cronius ruber specimen from Guinea, and Carlos Sánchez Nieto for his help on molecular laboratory work. Marcos Tavares and one anonymous reviewer provided useful comments and corrections that improved this paper. The second author was co-financed by a pre-doctoral fellowship of the University of Las Palmas de Gran Canaria.

\section{REFERENCES}

Afonso P., Porteiro F.M., Fontes J., et al. 2013. New and rare coastal fishes in the Azores islands: occasional events or tropicalization process? J. Fish. Biol. 83: 272-294. https://doi.org/10.1111/jfb.12162

Araújo R., Wirtz P. 2015. The decapod crustaceans of Madeira Island - an annotated checklist (Crustacea, Decapoda). Spixiana 38: $205-218$.

Atchison A.D., Sammarco P.W., Brazeau D.A. 2008. Genetic connectivity in corals on the Flower Garden Banks and surrounding oil/gas platforms, Gulf of Mexico. J. Exp. Mar. Biol. Ecol. 365: $1-12$. https://doi.org/10.1016/j.jembe.2008.07.002

Attrill M.J., Hartnoll R.G., Rice A.L. 1991. Aspects of the biology of the deep-sea crab Geryon trispinosus from the Porcupine Seabight. J. Mar. Biol. Assoc. U.K. 71: 311-328. https://doi.org/10.1017/S0025315400051626

Barton E.D., Arístegui J., Tett P., et al. 1998. The transition zone of the Canary Current upwelling region. Prog. Oceanogr. 41: 455-504. https://doi.org/10.1016/S0079-6611(98)00023-8

Biscoito M., Freitas M., Pajuelo J.G., et al. 2015. Sex-structure, depth distribution, intermoult period and reproductive pattern of the deep-sea red crab Chaceon affinis (Brachyura, Geryonidae) in two populations in the north-eastern Atlantic. Deep-Sea Res. I 95: 99-114.

https://doi.org/10.1016/j.dsr.2014.10.010

Brito A., Falcón J.M., Herrera R. 2005. Sobre la tropicalización reciente de la ictiofauna litoral de las islas Canarias y su relación con cambios ambientales y actividades antrópicas. Vieraea 33: 515-525.

Brito A., Clemente S., Herrera R. 2011. On the occurrence of the African hind, Cephalopholis taeniops, in the Canary Islands (eastern subtropical Atlantic): introduction of large-sized demersal littoral fishes in ballast water of oil platforms? Biol. Invasions 13: 2185-2189. https://doi.org/10.1007/s10530-011-0049-0

Brullé M. 1837-1839. Crustacés. In: Webb P.B., Berthelot S., Histoire naturelle des Iles Canaries, Zoologie, 2 (2: Entomologie): 13-18, 1 pl. (Crustacés) Atlas (1837); Text (1839). Paris.

Capart A. 1951. Crustacés Décapodes Brachyures. Expédition Océanographique Belge dans les Eaux Côtières Africaines de l'Atlantique Sud (1948-1949). Résultats Scientifiques 3: 11-205 + pl. $1-3$.

Crandall K.A., Fitzpatrick J.F.J. 1996. Crayfish molecular systematics: using a combination of procedures to estimate phylogeny. Syst. Biol. 45: 1-26 https://doi.org/10.1093/sysbio/45.1.1

Cuesta J.A., Almón B., Pérez-Dieste J., et al. 2016. Role of ships' hull fouling and tropicalization process on European carcinofauna: new records in Galician waters (NW Spain). Biol. Invasions 18: 619-630. https://doi.org/10.1007/s10530-015-1034-9

Dauvin J.C., Tous Rius A., Ruellet T. 2009. Recent expansion of two invasive crabs species Hemigrapsus sanguineus (de Haan, 1835) and $H$. takanoi Asakura and Watanabe 2005 along the Opal Coast, France. Aquat. Invasions 4: 451-465. https://doi.org/10.3391/ai.2009.4.3.3

Davie P. 2015. Cronius tumidulus (Stimpson, 1871). Accessed through: World Register of Marine Species at h t t p : / / w w w. marinespecies.org/a p hi a php? $\mathrm{p}=$ taxdetails \&id=422040 on 27/07/2016.

Dineen J.F., Clark P.F., Hines A.H., et al. 2001. Life history, larval description, and natural history of Charybdis hellerii (Decapoda, Brachyura, Portunidae), an invasive crab in the western Atlantic. J. Crustac. Biol. 21: 774-805.

https://doi.org/10.1651/0278-0372(2001)021[0774:LHLDAN] 2.0.CO;2

Estoup A., Largiadèr C.R., Perrot E., et al. 1996. Rapid one-tube DNA extraction for reliable PCR detection of fish polymorphic markers and transgenes. Mol. Mar. Biol. Biotech. 5: 295-298.

Fransen C.H.J.M. 1991. Preliminary report on Crustacea collected in the eastern part of the North Atlantic during the CANCAP and Mauritania expeditions of the former Rijksmuseum van Natuurlijke Historie, Leiden. Nationaal Naturhistorisch Museum, Leiden: i-vi + 1-200.

Fransen C.H.J.M. 2002. Taxonomy, phylogeny, historical biogeography, and historical ecology of the genus Pontonia Latreille (Crustacea: Decapoda: Caridea: Palaemonidae). Zool. Verh. Leiden 336: 1-433.

Fransen C.H.J.M. 2015. Cronius ruber (Lamarck, 1818). Accessed on 27/07/2016 through: World Register of Marine Species at h t t p : / / w w w. marines pecie s. or g/a p hi a. php? $\mathrm{p}=$ taxdetails \&id $=241109$

Friedlander A.M., Ballesteros E., Fay M., et al. 2014. Marine communities on oil platforms in Gabon, West Africa: high biodiversity oases in a low biodiversity environment. PLoS One 9: e103709. https://doi.org/10.1371/journal.pone.0103709

Galil B.S., Clark P.F., Carlton J.T. (eds) 2011. In the wrong place - Alien Marine Crustaceans: Distribution, Biology and Impact. Springer Series in Invasion Ecology 6.

González J.A. 1995. Catálogo de los Crustáceos Decápodos de las islas Canarias. Publicaciones Turquesa, Santa Cruz de Tenerife, 282 pp.

González J.A. 2016. Brachyuran crabs (Crustacea: Decapoda) from the Canary Islands (eastern Atlantic): checklist, zoogeographic considerations and conservation. Sci. Mar. 80: 89-102. https://doi.org/10.3989/scimar.04350.10A

González J.A., Martín L. Herrera R. et al. 2012. Cirripedia of the Canary Islands: distribution and ecological notes. J. Mar. Biol. Assoc. U.K. 92: 129-141. https://doi.org/10.1017/S002531541100066X 
Horta Costa B., Assis J., Franco G., et al. 2014. Tropicalization of fish assemblages in temperate biogeographic transition zones. Mar. Ecol. Prog. Ser. 504: 241-252. https://doi.org/10.3354/meps 10749

Landeira J.M., Lozano-Soldevilla F., Hernández-León S, et al. 2009. Horizontal distribution of invertebrate larvae around the oceanic island of Gran Canaria: the effect of mesoscale variability. Sci. Mar. 73: 757-767. https://doi.org/10.3989/scimar.2009.73n4757

Le Loeuff P., Intès A. 1968. La faune benthique du plateau continental de Côte d'Ivoire, récoltes au chalut, abondancerépartition-variations saisonnières (Mars 1966-Février 1967). Centre de Recherches Océanographiques, Abidjan, Doc. Scient. Provisoire 25: 1-78.

Lockett M.M., Gomon M.F. 2001. Ship mediated fish invasions in Australia: two new introductions and a consideration of two previous invasions. Biol. Invasions 3: 187-192. https://doi.org/10.1023/A:1014584201815

Luiz O.J., Allen A.P., Robertson D.R., et al. 2015. Seafarers or castaways: ecological traits associated with rafting dispersal in tropical reef fishes. J. Biogeogr. 42: 2323-2333. https://doi.org/10.1111/jbi.12574

Manfrin C., Turolla E., Chung J.S., et al. 2015. First occurrence of Callinectes sapidus (Rathbun, 1896) within the Sacca di Goro (Italy) and surroundings. Check List 11: 1640. https://doi.org/10.15560/11.3.1640

Manning R.B., Holthuis L.B. 1981. West African Brachyuran Crabs (Crustacea: Decapoda). Smithson. Contr. Zool. 306: i-xii + $1-379$.

Mantelatto F.L., Robles R., Schubart C.D., et al. 2009. Molecular phylogeny of the genus Cronius Stimpson 1860, with reassignment of $C$. tumidulus and several American species of Portunus to the genus Achelous de Haan, 1833 (Brachyura: Portunidae). In: Martin J.W., Crandall K.A., Felder D.L. (eds), Decapod Crustacean Phylogenetics. Crustac. Issues 18: 567-579.

Minchin D., Cook E., Clark P. 2013. Alien species in British brackish and marine waters. Aquat. Invasions 8: 3-19. https://doi.org/10.3391/ai.2013.8.1.02

Mittelstaedt E. 1983. The upwelling area off Northwest Africa-A description of phenomena related to coastal upwelling. Prog. Oceanogr. 12: 307-331. https://doi.org/10.1016/0079-6611(83)90012-5

Molnar J.L., Gamboa R.L., Revenga C., et al. 2008. Assessing the global threat of invasive species to marine biodiversity. Front. Ecol. Environ. 6: 485-492. https://doi.org/10.1890/070064

Monod T. 1956. Hippidea et Brachyura ouest-africains. Mém. I.F.A.N. 45: 1-674.

Moro L., Herrera R., Ortea J., et al. 2014. Aportaciones al conocimiento y distribución de los decápodos y estomatópodos (Crustacea: Malacostraca) de las islas Canarias. Rev. Acad. Canar. Cienc. 26: 33-82.

Ng P.K., Guinot D., Davie P.J. 2008. Systema brachyurorum: Part I. An annotated checklist of extant brachyuran crabs of the world. Raff. Bull. Zool. 17: 1-286.

Occhipinti-Ambrogi A. 2007. Global change and marine communities: Alien species and climate change. Mar. Pollut. Bull. 55: 342-352. https://doi.org/10.1016/j.marpolbul.2006.11.014

Pajuelo J.G., González J.A., Triay-Portella R., et al. 2016. Introduction of non-native marine fish species to the Canary Islands waters through oil platforms as vectors. J. Mar. Syst. 163: 23-30. https://doi.org/10.1016/j.jmarsys.2016.06.008

Perry A.L., Low P.J., Ellis J.R., et al. 2005. Climate change and distribution shifts in marine fishes. Science 308: 1912-1915. https://doi.org/10.1126/science.1111322

Rossignol M. 1957. Crustacés Décapodes marins de la région de Pointe-Noire. In: Collignon J., Rossignol M., Roux C., Mollusques, Crustacés, Poissons Marins des côtes d'A.E.F. en collection au Centre d'Océanographie de l'Institut d'Études Centrafricaines de Pointe-Noire. Paris: pp. 71-136.

Sant'Anna B.S., Watanabe T.T., Turra A., et al. 2012. First record of the non-indigenous portunid crab Charybdis variegata from the western Atlantic coast. BioInvasions Rec. 1: 11-16. https://doi.org/10.3391/bir.2012.1.1.03

Schubart C.D., Huber M.G.J. 2006. Genetic comparisons of German populations of the stone crayfish, Austropotamobius torrentium (Crustacea: Astacidae). Bull. Fr. Pêche Piscic. 380-381: 1019-1028. https://doi.org/10.1051/kmae:2006008

Schubart C.D., Reuschel S. 2009. A proposal for a new classification of Portunoidea and Cancroidea (Brachyura: Heterotremata) based on two independent molecular phylogenies. In: Martin J.W., Crandall K.A., Felder D.L. (eds), Decapod Crustacean Phylogenetics. Crustac. Issues 18: 533-549.

Schubart C.D., Cuesta J.A., Felder D.L. 2002. Glyptograpsidae, a new brachyuran family from Central America: larval and adult morphology, and a molecular phylogeny of the Grapsoidea. J. Crustac. Biol. 22: 28-44. https://doi.org/10.1163/20021975-99990206

Spalding M.D., Fox H.E., Allen G.R., et al. 2007. Marine ecoregions of the world: A bioregionalization of coastal and shelf areas. BioScience 57: 573-583. https://doi.org/10.1641/B570707

Spiridonov V.A., Neretina T.V., Schepetov D. 2014. Morphological characterization and molecular phylogeny of Portunoidea Rafinesque, 1815 (Crustacea Brachyura): Implications for understanding evolution of swimming capacity and revision of the family-level classification. Zool. Anz. 253: 404-429. https://doi.org/10.1016/j.jcz.2014.03.003

Streftaris N., Zenetos A., Papathanassiou E. 2005. Globalisation in marine ecosystems: the story of non-indigenous marine species across European seas. Oceanogr. Mar. Biol. 43: 419-453.

Tamura K., Stecher G., Peterson D., et al. 2013. MEGA6: Molecular Evolutionary Genetics Analysis version 6.0. Mol. Biol. Evol. 30: 2725-2729. https://doi.org/10.1093/molbev/mst197

Tavares M., Amouroux J.M. 2003. First record of the non-indigenous crab, Charybdis hellerii (A. Milne-Edwards, 1867) from French Guyana (Decapoda, Brachyura, Portunidae). Crustaceana 76: 625-630. https://doi.org/10.1163/156854003322316254

Tavares M., Mendonça Jr. J.B. 1996. Charybdis hellerii (A. Milne Edwards, 1867) (Brachyura: Portunidae), eighth non indigenous marine decapod recorded from Brazil. Crustac. Res. 25: $151-157$

Tavares M., Mendonça Jr. J.B. 2011. The occurrence of the IndoPacific swimming crab Scylla serrata (Forskål, 1775) in the Southwestern Atlantic (Crustacea: Brachyura: Portunidae). Aquat. Invasions 6: 49-51. https://doi.org/10.3391/ai.2011.6.S1.011

Triay-Portella R., González J.A., Santana J.I., et al. 2014. Reproductive pattern and egg development of the deep-sea crab Paromola cuvieri (Brachyura, Homolidae) around the Canary Islands (NE Atlantic). Deep-Sea Res. I 85: 1-14. https://doi.org/10.1016/j.dsr.2013.12.001

Triay-Portella R., Pajuelo J.G., Manent P., et al. 2015. New records of non-indigenous fishes (Perciformes and Tetraodontiformes) from the Canary Islands (eastern Atlantic). Cybium 39: 163-174.

Türkay M. 1976. Die Madeirensischen Brachyuren des Museu Municipal do Funchal und des Forschungs Instituts Senckenberg, I: Familien Dromidae, Homolidae, Calappidae, Leucosiidae, Cancridae, Portunidae, Xanthidae, Geryonidae, Goneplacidae und Palicidae (Crustacea: Decapoda). Bol. Mus. Mun. Funchal 30: $57-74$.

Türkay M. 1987. On the Mediterranean and eastern Atlantic records of Portunus sayi (Crustacea: Decapoda: Portunidae). Inv. Pesq. 51 (Suppl. 1): 63-66.

Turney S., Cameron E.R., Cloutier C.A., et al. 2015. Non-repeatable science: assessing the frequency of voucher specimen deposition reveals that most arthropod research cannot be verified. PeerJ 3: e1168. https://doi.org/10.7717/peerj.1168

Vergés A., Steinberg P.D., Hay M.E., et al. 2014. The tropicalization of temperate marine ecosystems: climate-mediated changes in herbivory and community phase shifts. Proc. R. Soc. B 281: $1-10$ https://doi.org/10.1098/rspb.2014.0846

Wernberg T., Bennett S., Babcock R.C., et al. 2016. Climate-driven regime shift of a temperate marine ecosystem. Science 353: $169-172$ https://doi.org/10.1126/science.aad8745

Wirtz P., Fricke R., Biscoito M.J. 2008. The coastal fishes of Madeira Island - new records and an annotated checklist. Zootaxa 1715: 1-26.

Wonham M.J., Carlton J.T., Ruiz G.M., et al. 2000. Fish and ships: relating dispersal frequency to success in biological invasions. Mar. Biol. 136: 1111-1121. 